\title{
Mobilitási szokások változásai a Covid19-világjárvány idején Changing mobility behaviour during
the Covid19 pandemic
}

Szerzők: Miskolczi Márk - Bauer Béla² - Déri András ${ }^{3}$ - Kovács Tamás ${ }^{4}$

\begin{abstract}
A Covid19-világjárvány jelentős recessziót eredményezett a turizmus szektorban. A korlátozó intézkedések enyhítése mellett a lakosság hozzáállása is nagyban befolyásolja a válságból való a kilábalást, ezért kutatócsoportunk az egyes közlekedési módokkal kapcsolatos társadalmi attitüdök, a világjárvány alatti turisztikai szokások, valamint a járvány enyhülését, megszűnését követő utazási motiváció feltárását tűzte ki célul. A kutatási célok megvalósításához kvalitatív (6 fókuszcsoportos interjú) és kvantitatív adatfelvételi módszereken alapuló, utóbbi esetében a felnőtt magyarországi lakosságra vonatkozóan reprezentatív ( $n=3025)$, kutatás készült. A kutatásba bevont alanyok szerint a járvány teljes leküzdéséig legfeljebb a belföldi turizmus iránti kereslet erősödhet, azt követően azonban a nemzetközi turizmus hirtelen fellendülése valószínüsíthető. A kérdőíves, reprezentatív megkérdezés alapján a lakosság körében óvatos, kockázatkerülő magatartás mutatkozik. A válaszadók jelentős része arról számolt be, hogy jövőbeni utazásai során, a Covid19-világjárványt követő időszakban is körültekintőbb lesz a higiéniai szabályok betartásával kapcsolatban. A szigorúbb egészségvédelmi intézkedések iránti erősödő igény tudatában érdemes újragondolni a közlekedési és turisztikai szolgáltatások konstrukcióját (pl. repülőgépek férőhelye, egészségügyi ellenőrzések, szálláshelyek és egyéb szolgáltatók hosszú távú járványügyi védekezése), ami nagyban befolyásolhatja a szektor fellendülését.
\end{abstract}

The Covid19 outbreak has led to a significant recession in the tourism sector. The recovery from the crisis, in addition to the restrictive measures, is also heavily influenced by the attitudes of society. Based on this, our research team aimed to explore changes in social attitudes towards different modes of transport and tourism-related consumption. To achieve this, data collection in two phases: qualitative ( 6 focus group interviews) and quantitative representative $(n=3025)$ surveys were conducted. Focus group interviews indicated that domestic tourism will be stronger until the Covid19 pandemic is over, but a quick recovery of international tourism is expected afterwards. The survey revealed cautious, risk-averse attitude among the respondents. A significant proportion of subjects reported that they would be more careful about hygiene during travel, even when the pandemic is over. With this mind, transport and tourism services may need to rethink (e.g., empty middle seats on flights, health checks, epidemic prevention by different tourism service providers) to ensure the recovery of the sector.

Kulcsszavak: turizmus, Covid19-világjárvány, mobilitási szokások, fókuszcsoportos interjúk, kérdőíves megkérdezés.

Keywords: tourism, Covid19 pandemic, mobility habits, focus group interviews, questionnaire.

\section{Bevezetés}

Napjainkban valamennyi tudományterület és iparág a jelenleg zajló világjárvány (Covid19-pandémia) megfékezésére, illetve a járvány következtében fel-

\footnotetext{
'tudományos segédmunkatárs, KTI Közlekedéstudományi Intézet Nonprofit Kft., miskolczi.mark@kti.hu

${ }^{2}$ tudományos főmunkatárs, KTI Közlekedéstudományi Intézet Nonprofit Kft., bauerbela@gmail.com

${ }^{3}$ tudományos munkatárs, KTI Közlekedéstudományi Intézet Nonprofit Kft., deri.andras@kti.hu

${ }^{4}$ kutatócsoport-vezető, KTI Közlekedéstudományi Intézet Nonprofit Kft., kovacs.tamas@kti.hu
} 
lépő negatív hatások minimalizálására törekszik. A tercier szektor kitettsége a pandémia kitörésétől kezdődően jelentős, a járvány a turizmus szektor valamennyi alágazatában (szállodaipar, vendéglátás) recessziót okozott.

A Covid19 (CoronaVirus Disease-19) megbetegedést a SARS-CoV-2 (angolul: Severe Acute Respiratory Syndrome Coronavirus 2) kórokozó okozza (JOO et al. 2019). A koronavírusok közé tartozik a 2000-es években endémiát (lokális járványokat) és ugyancsak átmeneti gazdasági visszaesést okozó SARS-vírus is, mely Kína gazdaságában hozzávetőlegesen 14,8 milliárd dollárra tehető veszteséget okozott (WORLD BANK 2007), valamint a 2012-ben felfedezett MERS-CoV vírusfaj, mely a 2010-es évek elején többszáz halálos fertőzést okozott a közel-keleti régióban (BAUM-HAI 2020, FELKAI 2021).

Az Egészségügyi Világszervezet (World Health Organization - WHO) által 2020. március 11-én világjárvánnyá nyilvánított megbetegedés (WHO 2021) társadalmi-gazdasági hatásai már a pandémia elsó évében is rendkívüliek voltak. A járványhelyzet nemcsak a mindennapi tevékenységek módját alakította át (pl. távmunka terjedése, fokozottabb támaszkodás az olyan digitális megoldásokra, mint az online videótelefon-szoftverek használata), hanem alapjaiban változtatta meg a társadalom turisztikai célú utazási lehetőségeit is. A járványügyi kockázat csökkentését szolgáló intézkedések az egyéni mobilitási lehetőségek jelentős mértékú korlátozásával jártak, mellyel öszszefüggésben felvetődik a járvány személyközlekedésre (és egyben turizmusra) gyakorolt közép- és hosszú távú hatásvizsgálatának szükségessége.

Közlekedés nélkül turizmusról sem beszélhetünk, így az iparág szempontjából is kiemelt fontosságú az esetlegesen változó mobilitási igények, fogyasztói attitúd feltárása és folyamatos - aktuális változásokhoz igazodó - monitorozása (JÁSZBERÉNYI-PÁLFALVI 2009， MUNKÁCSY 2018, MICHALKÓ-ILYÉS 2020).

A fentiekből kiindulva a Közlekedéstudományi Intézet kutatócsoportjának ${ }^{5}$ célja a személyközlekedési szokások vizsgálata volt a Covid19 vonatkozásában. Kutatásunk során az egyes közlekedési módokkal kapcsolatos társadalmi attitúdöket, valamint a pandémia elsô két hulláma alatti (2020 tavasza és tele közötti) turisztikai szokásokat, illetve a járvány enyhülését, megszúnését követő utazási motivációt vizsgáltuk.

A kutatási célok megvalósításához szekvenciális, hibrid (kvalitatív - fókuszcsoportos interjúk és kvantitatív - kérdőíves megkérdezés) adatfelvéte- li módszereken alapuló kutatást folytattunk le. A szektort érintő kihívások vonatkozásában feltáró kutatásunk során az alábbi három kutatási célt fogalmaztuk meg:

- a magyarországi lakosság Covid19 alatti mindennapi és szabadidős (turisztikai) célú helyváltoztatási szokásainak megismerése (közlekedési munkamegosztás változásai),

- a magyarországi lakosság utazási motivációi, a pandémia alatti utazási hajlandóság feltárása,

- a magyarországi lakosság nemzetközi turizmussal, légi közlekedéssel kapcsolatos attitûdjének elemzése.

Az alábbi tanulmányban az adatfelvételek turizmushoz kapcsolódó részeredményeit ismertetjük a következők szerint: a második fejezetben a Covid19-pandémia turisztikai célú közlekedésre gyakorolt hatásait foglaljuk össze, ezt követően (3. fejezet) a kutatás módszertani hátterének részletes bemutatására kerül sor. A negyedik fejezet a fókuszcsoportos beszélgetések fontosabb eredményeit, valamint a kérdőíves adatfelvétel alapján tett megállapításokat rendszerezi. A tanulmány utolsó fejezetében (5.) a várható fogyasztói attitúdváltozások turisztikai hatásaira, valamint a jövőbeni kutatási irányokra hívjuk fel a figyelmet.

\section{Közlekedés és turizmus - a Covid19-világjárvány hatásai}

A Központi Statisztikai Hivatal (KSH) adatai alapján 2020 májusában a távmunkában dolgozó lakosság aránya elérte a 17\%-ot (kb. 760 ezer fó), mely értelemszerúen a közlekedési eszközök használatát is visszaszorította (KSH 2021a). A Covid19világjárvány súlyos gazdasági következményei a makrogazdasági mutatók alapján is jól leírhatók: Magyarország GDP-je 2020-ban 5,1\%-kal maradt el a 2019. évi szinthez képest (KSH 2021b).

A turizmus szektort 2020-ban rekordalacsony teljesítmény jellemezte. A nemzetközi turizmus visszaesése elsődlegesen a légi közlekedésben volt érzékelhetó (MISKOLCZI et al. 2021). Az International Finance Corporation (IFC) jelentése alapján a légi személyszállítás a világ GDP-jének mintegy 10\%-át teszi ki, amivel kb. 330 millió munkahelyet biztosít világszerte (IFC 2020).

A Turisztikai Világszervezet (UNWTO) 2020 decemberében publikált jelentése alapján a nemzetközi turistaérkezések volumene 2020-ban 73 százalékpontos visszaesést mutatott az előző évhez képest, melyet a Covid19-pandémia megfé-

KTI Közlekedéstudományi Intézet Nonprofit Kft., Stratégiai, Kutatăs-Fejlesztési és Innovációs Igazgatóság, Stratégiai és Koordinációs Központ, Társadalomtudományi Kutatócsoport 
kezése céljából bevezetett kiutazási korlátozások, valamint az utazók csökkenő bizalma és erősödó kockázatkerülő attitúdje eredményezett (UNWTO 2020). Mindezek következtében a légi személyszállítás teljesítménye a 30 évvel ezelótti szintre esett vissza (UNWTO 2020, IFC 2020).

2020 nyarán - a járványhelyzet átmeneti enyhülése következtében - az OECD-országokban a belföldi turizmus minimális fellendülése volt ér-
QIU et al. 2020) hangsúlyozza a légi közlekedésbe, illetve a nemzetközi turizmusba vetett fogyasztói bizalom gyengülését, valamint ezen közlekedési mód használatának észlelt járványügyi kockázatát. Felmerüló kérdés továbbá, hogy az Európai Unióba irányuló nem létfontosságú (pl. szabadidős célú) utazásokra vonatkozó korlátozások enyhülésével (EC 2021) milyen piaci átrendezódésre lehet számítani 2021 második felében.

1. táblázat

A Budapest Liszt Ferenc Nemzetközi Repülótér utasforgalmának változásai 2016 és 2020 között

\begin{tabular}{|c|c|c|c|c|}
\hline Év & Induló utasok (fö) & Változás az előző évhez képest (\%) & Érkező utasok (fö) & Változás az előző évhez képest (\%) \\
\hline 2016 & 5519361 & & 5607041 & \\
\hline 2017 & 6322608 & $+14,6$ & 6404714 & $+14,23$ \\
\hline 2018 & 7130752 & $+12,78$ & 7225008 & $+12,80$ \\
\hline 2019 & 7819045 & $+9,65$ & 7898262 & $+9,32$ \\
\hline 2020 & 1857432 & $-76,24$ & 1935044 & $-75,50$ \\
\hline
\end{tabular}

Forrás: saját szerkesztés a KSH (2021c) alapján

zékelhetó, ami az összes turisztikai kiadás 75\%-át tette ki, míg az Európai Unióban a belföldi turisztikai kiadások mértéke 1,8-szoros volt a nemzetközi utazásokkal összehasonlítva (UNWTO 2021).

A gazdasági recesszió jelei a hazai légi személyszállításban is kimutathatóak. A Budapest Liszt Ferenc Nemzetközi Repülótér KSH által nyilvántartott utasforgalmi adatai alapján látható, hogy az utolsó öt teljes évet alapul véve (2016-2020) a repülótér utasforgalma (az érkező és induló utasokat is beleértve) 2016 és 2019 között - folyamatosan csökkenő mértékben ugyan (1. táblázat), de - növekedett. A pandémia következtében a 2020. évi forgalmi adatokban 2019-hez viszonyítva kiugró mértékú (átlagosan 75,87\%-os) visszaesés látható.

Az iparág valamennyi alszektora jelenleg a kilábalás lehetốségeit keresi. Az UNWTO elórejelzése szerint a nemzetközi turizmus tekintetében a 2019es szintre való visszatérés akár 2-4 évig is eltarthat (UNWTO 2020). A gazdasági mutatók jelentős változását eredményezhetik az aktuális járványhullám enyhülését, illetve a lakosság átoltottságának növekedését követő nemzetközi intézkedések (pl. beutazási feltételek enyhítése, védettségi igazolvánnyal rendelkezók mobilitása), ugyanakkor az utazási motivációt az egyénhez kötődő tényezők (fogyasztói bizalom, motiváció, attitúd) is befolyásolhatják (BAKAR-ROSBI 2020).

Számos iparági jelentés (ETC 2021, GLOBALDATA 2021, UNWTO 2021) és kutatás (ŠKARE et al. 2021, HIGGINS-DESBIOLLES 2021,

\section{A kutatás módszertana}

A kutatás első lépéseként fókuszcsoportos interjúkat folytattunk, melyek a kvantitatív kutatási fázis céljainak, kérdéseinek pontosítását szolgálták. A kvalitatív, részben strukturált adatfelvételi módszer lehetóvé teszi, hogy a szabadon folyó csoportbeszélgetések alapján a vizsgált problémát - jelen esetben a pandémia közlekedési attitúdre, turisztikai szokásokra gyakorolt hatásait - több megközelítésből is megvizsgálhassuk (MALHOTRADASH 2016).

A járványügyi helyzetre való tekintettel az adatfelvételre ugyan személyesen, de a fizikai távolságtartást és egészségvédelmi eloórárásokat betartva alacsonyabb létszám mellett (4 fő/csoport) került sor.

A kutatás keretében összesen 6 fókuszcsoportos beszélgetést ${ }^{6}$ folytattunk le, melyek keretében szociodemográfiai ismérvek alapján különböző hátterú alanyok bevonására törekedtünk. Ebből kiindulva a fókuszcsoportos interjúkon különböző korcsoportba tartozó, eltéró iskolai végzettséggel rendelkező alanyok kapcsolódtak be (2. táblázat). A kutatási alanyok kiválasztásának fontos szempontja volt ugyanakkor az is, hogy rendelkezzenek légi közlekedési tapasztalattal, illetve, hogy - a világjárványt megelőző időszakban - rendszeres résztvevői legyenek turisztikai célú, repülóvel tett utazásoknak. A fókuszcsoportos interjúkra négy

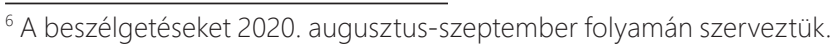


településen, Budapesten (3 csoport), Tatán (1 csoport), Debrecenben (1 csoport), valamint Pécsett (1 csoport) került sor.

A 90-110 perces időtartamú fókuszcsoportos interjúk vezérfonalát az általános mobilitási, illetve repülési szokások, a légi közlekedés megítélése, fenntarthatósági aspektusainak feltárása, valamint a Covid19 turizmusra gyakorolt hatásának feltárása adta.
A fókuszcsoportos beszélgetések rámutattak, hogy válaszadóink körében a pandémia hatására jelentősen csökkent a közösségi közlekedés, miközben jelentôsen növekedett a személygépkocsi és a kerékpár, valamint egyéb mikromobilitási eszközök (pl. roller) használata, melynek oka - elsődlegesen - a járványhelyzetból adódó kockázatok minimalizálása. A fókuszcsoportos beszélgetésekbe bevont alanyok jelentős része azonban ideiglenesnek ítél-

Fókuszcsoportos beszélgetések: szúrési kritériumok, csoportösszetétel

\begin{tabular}{|c|c|c|c|c|c|c|c|c|c|c|}
\hline \multirow[t]{2}{*}{ Kód } & \multirow[t]{2}{*}{ Régió } & \multirow[t]{2}{*}{ Helyszín } & \multicolumn{3}{|c|}{ Legmagasabb iskolai végzettség } & \multicolumn{5}{|c|}{ Korcsoport } \\
\hline & & & Szakmunkásképző & Középfokú & Felsőfokú & $18-29$ & $30-39$ & $40-49$ & 50-59 & $60-75$ \\
\hline BP1 & Pest megye & Budapest & 1 & 2 & 1 & - & - & - & 2 & 2 \\
\hline BP2 & & & 1 & 2 & 1 & 2 & 2 & - & - & - \\
\hline BP3 & & & - & 2 & 4 & - & - & 3 & 2 & 1 \\
\hline T1 & $\begin{array}{c}\text { Komárom-Esztergom } \\
\text { megye }\end{array}$ & Tata & 1 & 2 & 1 & 2 & 2 & - & - & - \\
\hline P1 & Baranya megye & Pécs & 1 & 1 & 2 & - & - & - & 2 & 2 \\
\hline D1 & Hajdú-Bihar megye & Debrecen & 2 & 2 & - & - & 2 & - & - & 2 \\
\hline
\end{tabular}

Forrás: saját szerkesztés

A fókuszcsoportos interjúk eredményeiból kiindulva kvantitatív adatfelvételre is sor került $\left(\mathrm{CAPI}^{7}\right)$, melynek keretében a légi közlekedés lakossági megítélését, valamint a pandémia közlekedési és turisztikai szokásokra gyakorolt hatását tártuk fel. A kérdőíves vizsgálat keretében 3025 válaszadó személyes lekérdezésére került sor. Az adatfelvétel Magyarország lakosságának szempontjából, a szociodemográfiai kontrollkategóriák alapján (18-75 év közötti lakosság körében életkorra, nemre, településtípusra, régiókra és településnagyságra), reprezentatívnak tekinthető. A strukturált kérdőív szelektív zárt és értékelőskála-alapú (1-5) kérdéseket tartalmazott. A tanulmányban a központi témakörhöz kapcsolódó részeredményeket (mobilitási szokások átrendeződése, pandémia és turizmus) mutatjuk be.

\section{Eredmények}

\subsection{A FÓKUSZCSOPORTOS INTERJÚK LEGFONTOSABB EREDMÉNYEI}

A fókuszcsoportos interjúk eredményeit két fő témakör mentén mutatjuk be:

- mobilitási szokások és a vírushelyzet összefüggései,

- részvételi hajlandóság turisztikai célú (belföldi, nemzetközi) utazásokon. te meg a Covid19 mobilitási szokásokra gyakorolt hatásait, és a járványhelyzet lefolyását követően a szokások gyors visszarendeződését prognosztizálják. "Akinek pénze lesz, az ugyanúgy megy, mint eddig. Akinek meg nem, az ugyanúgy marad otthon, mint eddig. Ennyi!" $(35$, D1)

A napi ingázáson kívüli helyváltoztatásokkal kapcsolatban erôsen elutasító attitúd mutatkozott, főként az idősebb (60+) alanyok körében, akik többsége a járványhelyzetre való tekintettel tartózkodott a külföldi utazásoktól. „Hát, mentem volna már idén, de úgy gondolom, hogy idén mindenkinek kellene ülni itthon a saját országában." (64, BP1) "Én se megyek, minden évben mi is mentünk valamerre külföldre, idén sajnos ez nem fért bele, mert elmúltam 60 éves, tehát a veszélyzónában vagyok, és nem szeretnék semmit elkapni." (62, BP1)

A fiatalabbak narratíváit gyakrabban jellemezte a kisebb óvatosság, esetükben a külföldi utakat inkább a légi közlekedés és a határzárás bizonytalansága gátolta. "Nem azért [nem repülök], mert félnék, vagy valami, hanem mert nem tudjuk összehozni úgy a szervezési részét, hogy jó legyen." (31, BP3)

Valamennyi csoportban felmerült a belföldi turizmus jelentőségének növekedése, abban azonban, hogy ez tartósabb változásokat is eredményez-e a szektorban, nem volt konszenzus. Rövid távon a félelem, illetve a karanténintézkedések következményeként merült fel a belföldi

A CAPI (Computer Assisted Personal Interviewing) a kvantitatív adatgyüjtés egy technikája, mely esetében egy kérdezőbiztos a kutatásba bevont alany válaszait egy digitális eszközön (pl. laptop, tablet) megjelenített kérdőívfelületen rögzíti (BABBIE 2015). 
turizmus erősödése. "Én azt gondolom, hogy most minden országban a belföldi turizmus fog fölerôsödni csakúgy, mint nálunk. Tehát végre az emberek felfedezik a Balatont újra (...) nem kell attól félni, hogy valami idegen országban karanténba kerülünk." (24, T1)

Ahol a turizmus gazdasági vonatkozásai is előkerültek, ott egységesen a jelentős veszteségek narratívája hatotta át a diskurzusokat, amelyek részben a visszaeső turizmus személyes tapasztalatából (főleg Budapesten), részben a médiatudósításokból táplálkoztak. A belföldi turizmus költségeinek emelkedését egyik alanyunk éppen a versenyhelyzet szúkülésével magyarázta. "Hogy vérszemet kapnak a szállásadók, és olyan árakat kérnek, mintha külföldre mennél. De ez most is így van, csak lehet, hogy ez még fokozódik" $(27, D 1)$

Egyes diskurzusok szerint a belföldi turizmus iránti kereslet a senior korcsoport körében erősödhet, melynek oka a belföldi utazásokkal kapcsolatban észlelt alacsonyabb járványügyi kockázat. A belföldi turizmus ugyanakkor több beszélgetés alkalmával inkább másodlagos attrakcióként került elő. A külföldi desztinációk versenyelőnyével és a nemzetközi utazások járvány utáni gyors visszatérésével egyértelmú csoportkonszenzus mutatkozott több esetben is. "Majd ha már kerekesszék vagy bot vagy nem tudom én mi, vagy már nem visz úgy a lábam, akkor majd jöhetnek Magyarország szépségei (...) de amíg bírom, inkább külföldre megyek.” (65, BP1) „Bárkivel beszéltem azért mindenki azt mondta, hogy jó-jó, szép nagyon Magyarország, meg én is aláirom, gyönyörü helyei vannak, de azért a tenger az tenger, és csak külföldre akar menni, mert egy Colosseumot nem lehet idehozni." (52, P1) A fókuszcsoportos beszélgetések főbb megállapításait a 3. táblázat foglalja össze.

\subsection{A KÉRDÖÍVES ADATFELVÉTEL LEGFONTOSABB EREDMÉNYEI}

\subsubsection{Szociodemográfiai ismérvek}

A 3025 fóből álló minta nemek szerinti megoszlása kiegyenlített (51\% férfi, 49\% nó). A minta a régiók lakosságaránya alapján reprezentatívnak tekinthető: a válaszadók körét legnagyobb arányban (29\%) a közép-magyarországi (Budapest, Pest megye) lakosok alkotják, míg az ország többi régióját egyenletes arányban (10\%-15\%) képviseli a kutatásba bevont többi alany. Településtípusok szerinti felosztás alapján a válaszadók $17 \%$-a budapesti lakos, $21 \%$ megyeszékhely vagy megyei jogú város, többségük pedig egyéb város (32\%) vagy község, falu lakosa (31\%).

A kutatásban valamennyi korcsoport képviseltette magát, a válaszadók átlagéletkora 44,75 év. A korcsoportok szerinti megoszlás kiegyenlített (18\%-22\% közötti), a mintát legnagyobb arányban a 60-75 éves korcsoport alkotja (22\%).

A kutatási alanyok végzettség szerinti megoszlása alapján a mintában a szakközépiskolai, gimnáziumi érettségivel rendelkező válaszadók aránya a legmagasabb (28\%). A válaszadók 20\%-a szakmunkásképző, illetve érettségit nem adó szakiskolai végzettséggel, $17 \%$ BSc, BA alapszakos fóiskolai diplomával, 15\% pedig középiskola utáni nem felsőfokú végzettséggel (technikum, OKJ, FOKSZ stb.) rendelkezik. A teljes minta 10\%-a mesterképzésben vagy osztatlan képzési formában szerzett diplomát. PhD vagy DLA fokozattal a minta $1 \%$-a rendelkezik.

Munkarend szerinti megoszlás alapján a válaszadók 52\%-a teljes munkaidőben, 7\%-a részmunkaidőben van foglalkoztatva. A nyugdíjas válaszadók teljes mintához viszonyított aránya 19\%, melynek 15\%-át öregségi, 4\%-át pedig rokkantnyugdíjas vá-

Fókuszcsoportos beszélgetések fóbb megállapításai

\begin{tabular}{|c|c|c|}
\hline Témakör & Megállapitás & Turisztikai relevancia \\
\hline $\begin{array}{l}\text { Személyközlekedés és Covid19- } \\
\text { világjárvány }\end{array}$ & $\begin{array}{l}\text { Közösségi közlekedés szerepének rövid távú } \\
\text { gyengülése, személygépkocsival történő közlekedés } \\
\text { erösödése. }\end{array}$ & $\begin{array}{l}\text { Turisztikai célú személygépkocsi-használat, } \\
\text { kerékpáros turizmus további erösödése várható. }\end{array}$ \\
\hline $\begin{array}{l}\text { Turisztikai célú belföldi utazások a } \\
\text { Covid19-világjárvány után }\end{array}$ & $\begin{array}{l}\text { Belföldi turizmus időszakos - kizárólag rövid távú - } \\
\text { erôsödése. Elsődleges célcsoport: szenior szegmens. }\end{array}$ & $\begin{array}{l}\text { Szenior belföldi turizmus erósödése rövid távon, } \\
\text { a pandémia végéig várható. }\end{array}$ \\
\hline $\begin{array}{l}\text { Turisztikai célú nemzetközi utazások a } \\
\text { Covid19-világjárvány után }\end{array}$ & $\begin{array}{l}\text { Versenyelönye - a belföldi turizmussal szemben - } \\
\text { valószinuúsithetốen visszatér a járvány lefolyását } \\
\text { követöen. }\end{array}$ & $\begin{array}{l}\text { Rekreációs üdülések, szabadtéri programok és } \\
\text { látnivalók, aktív és ökoturizmus iránti kereslet } \\
\text { erósödése várható. }\end{array}$ \\
\hline
\end{tabular}

Forrás: saját szerkesztés 
laszadók alkotják. A kutatásba bevontak körében 6\%-6\%-os arányban jelentek meg a tanulók, illetve az álláskereső́k. A GYES, GYED, illetve GYÁS igénybe vevói a teljes minta 4\%-át alkotják. Egyéb tevékenységi formába (pl. háztartásbeli, szociális segélyezett, jelenleg állást nem kereső munkanélküli) a válaszadók 3\%-a sorolta magát, míg $2 \%$-uk egyéb nyugdíj, vagy nyugdíjjellegú ellátásban részesült az adatfelvétel időpontjában.

Társadalmi csoportok szerint - önbesorolás alapján - a válaszadók 40\%-a középosztályba, 23\% a munkásosztályba, $22 \%$ az alsó középosztályba, 11\% a felső középosztályba, 3\% az alsóosztályba, 1\% pedig a felsőosztályba tartozik.

\subsubsection{Mobilitási szokások átrendeződése a világjárvány hatására}

A magyarországi felnőtt lakosságra reprezentatív adatfelvétel során az egyes közlekedési módok használatát, valamint a közlekedési munkamegosztás változásait vizsgáltuk a Covid19-világjárvány vonatkozásában.
Kiemelendô továbbá a taxik (5,8\%), a jármúmegosztó szolgáltatók (pl. Mol Limo, Drive Now, GreenGo) $(4,6 \%)$, illetve a közösségi közlekedés $(6,8 \%)$ iránti kereslet visszaesése, ahol a fizikai távolságtartás fenntartása kevésbé oldható meg. A megosztáson alapuló üzleti modellre épült közlekedési megoldások használata a 18-29 és a 40-49 éves korcsoportok körében változott a legkevésbé, a megosztáson alapuló közlekedési szolgáltatások elsődleges célcsoportja továbbra is inkább a fiatalabb szegmens.

$\mathrm{Az}$ adatok alapján az összes válaszadó 6,8\%-a fordult el a közösségi közlekedéstől. Ez nagyobb arányban jellemzó a 30-39 éves korcsoport $(8 \%)$, a felsôfokú végzettséggel rendelkezôk $(9,9 \%)$, valamint a megyei jogú városokban lakó alanyok (10,4\%) körében. A legkisebb visszaesést az egyéni motorizált közlekedési mód terén tapasztalhatjuk (személygépjármú-használat), valamint az egyéni nem motorizált alternatívák (kerékpározás: 1,2\%; gyaloglás: $0,6 \%$ ) esetében.

\section{Egyes közlekedési módokat elhagyók aránya (\%)}

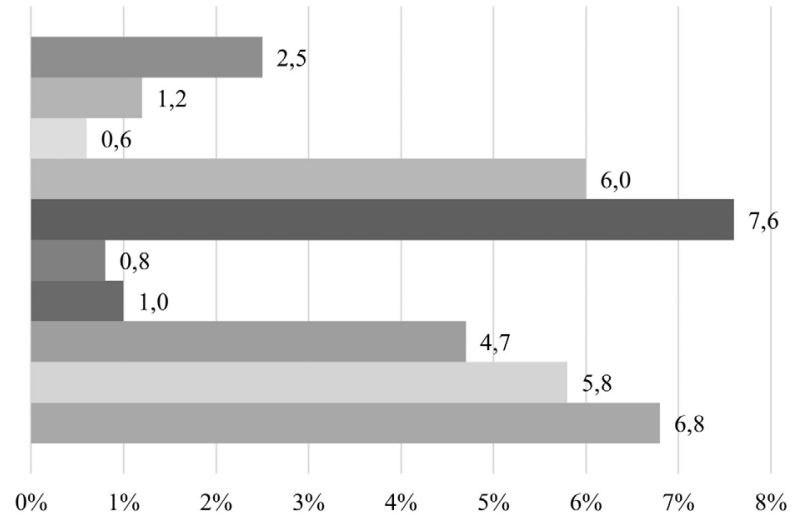

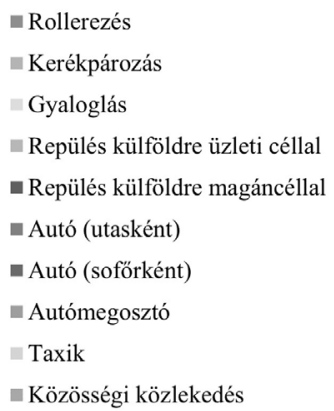

Forrás: saját szerkesztés

A teljes mintát $(\mathrm{n}=3025)$ alapul véve a légi közlekedés kihasználtsága csökkent a legnagyobb mértékben (1. ábra). A válaszadók 7,6\%-a teljesen elhagyta e közlekedési formát, melyhez az utazási kedv csökkenése mellett - értelemszerúen - a kiutazási korlátozások szigorodása is hozzájárult. A repülővel megvalósuló hivatásforgalmi (MICE) utazások mértéke ugyancsak jelentósen visszaesett a többi közlekedési móddal összehasonlítva (6\%). A légi közlekedést elhagyók körében nagyobb arányban vannak jelen a közép- (9\%) és felsőfokú végzettséggel rendelkezők $(11,7 \%)$.
A pandémia közlekedési eszközhasználatra gyakorolt hatásait vizsgálva megállapítható, hogy a személygépjármú-használat gyakoriságában történt leginkább változás (2. ábra). A járvány előtti időszakhoz viszonyítva utasként $12,2 \%$, sofőrként $13,8 \%$ gyakrabban vett igénybe személygépjármúvet. A nem motorizált módok esetében leginkább a gyalogos közlekedés részaránya emelkedett (23,8\%-kal), továbbá a kerékpározás szerepének erősödése számottevő (18,5\%). Az egyéb közlekedési módok használati gyakorisága csak minimális mértékben mutatott növekedést ( $\%$ alatt). 
Egyes közlekedési módok használatának növekedése a pandémia ideje alatt (\%)

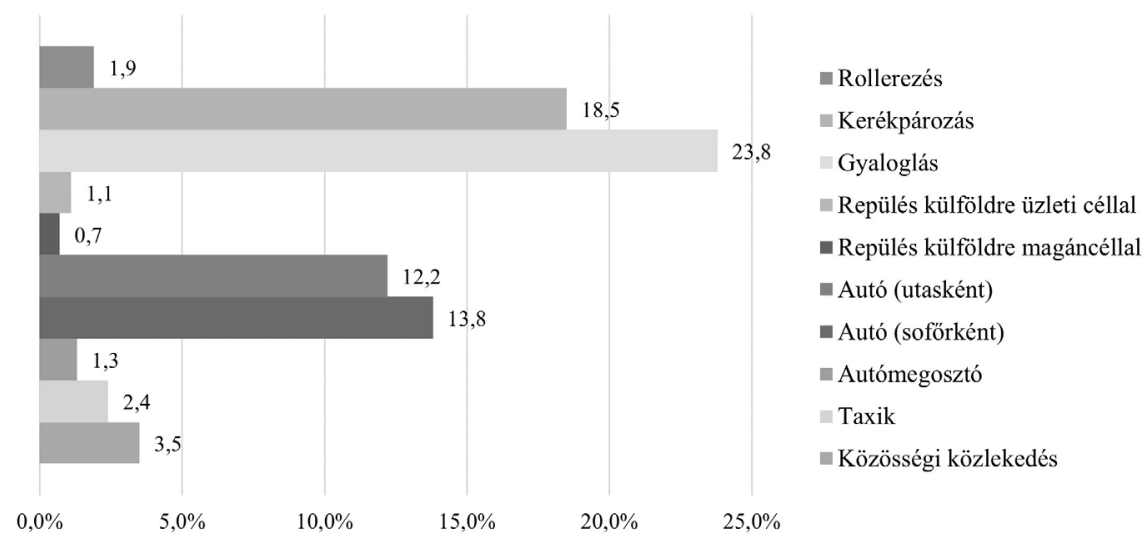

Forrás: saját szerkesztés

\subsubsection{Pandémia és turizmus}

A kérdőív második részében a turisztikai célú utazási motivációkat, valamint a légi közlekedési szokásokat vizsgáltuk. A legnagyobb átrendeződés a légi közlekedési szokások esetében tapasztalható. Repülővel tett turisztikai célú utazásokon a válaszadók a pandémia elótt évente többször (teljes minta 5\%-13\%-a) vagy évente (7\%-26\% között) vettek részt. Ennél gyakrabban csupán az alanyok 1\%-2\%-a utazott repülóvel.

A Covid19-világjárvány hatására a válaszadók 60\%-a egyáltalán nem vett részt turisztikai célú utazásokon 2020-ban (3. ábra). Ez nagyobb arányban jellemző (79\%) a 60-75 éves korcsoportra, va- lamint az alapfokú végzettséggel rendelkező (74\%), továbbá a magukat az alsóosztály társadalmi csoportba soroló alanyok (83\%) körében.

Belföldi utazásokon - a világjárvány ellenére - 32\% vett részt, nagyobb arányban a 18-29 éves korcsoport $(39 \%)$, valamint az önmagukat középosztályba soroló válaszadók (37\%). Belföldi utazásaik során a válaszadók túlnyomó többségben személygépkocsival közelítették meg a turisztikai desztinációkat.

A válaszadók többsége utoljára 2020-ban (22\%) vagy régebben $(35 \%)$ járt a Budapest Liszt Ferenc Nemzetközi Repülótéren. A 2020-2021-ben (pl. fél éve - 9\%; elmúlt hónapban - 2\%) tett repülótéri látogatások aránya elenyésző, mely vélhetóen össze-

\section{Utazási hajlandóság a pandémia alatt, korcsoportonként (\%)}

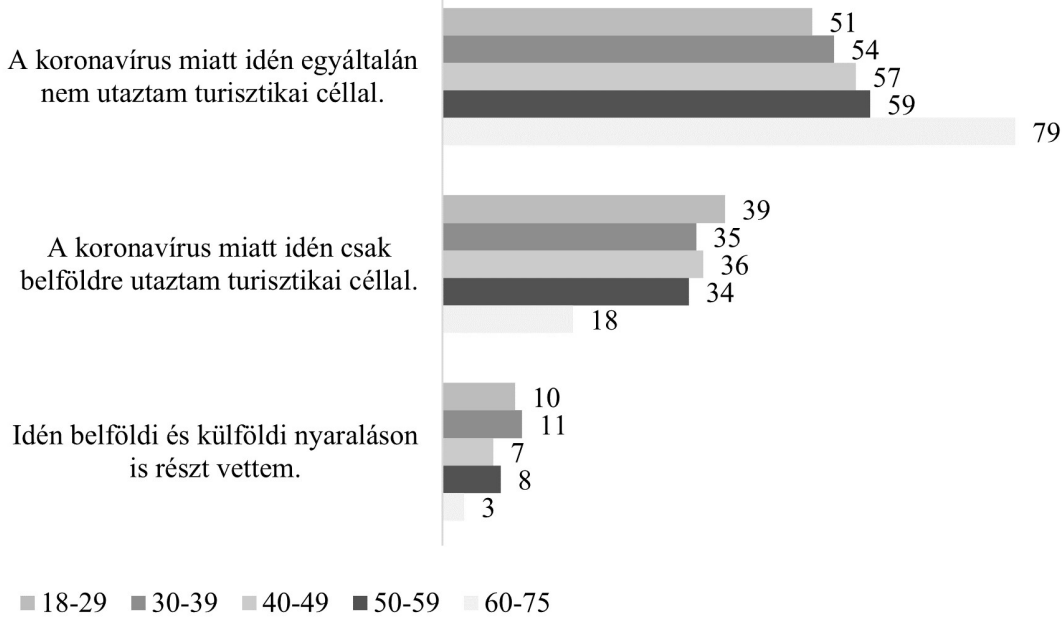

Forrás: saját szerkesztés 
függésben áll a Covid19-világjárvány miatt bevezetett kijárási és utazási korlátozásokkal.

Turisztikai célból belföldre és külföldre is csupán a válaszadók $8 \%$-a utazott. Nagyobb utazási hajlandóság a 30-39 éves korcsoport (11\%), valamint a magukat a felső középosztályba soroló alanyok (14\%) körében látható, azonban arányuk 15\% alatti.

A teljes minta $66 \%$-a rekreációs üdülés céljából utazott. A hagyományos értelemben vett nyaralás mint motiváció a 18-29, valamint a 40-49 éves korcsoport körében jelenik meg nagyobb mértékben (71\%-71\%). Üdülés céljából tett utazás az alapfokú végzettséggel rendelkezők esetében kevésbé (45\%), a felsőfokú végzettségúek körében azonban az átlagnál jóval magasabb arányban (73\%) jellemző.

Fontos szerepe van továbbá a VFR (visiting friends and relatives - család és barátok meglátogatása) turizmusnak is (14\%). A teljes mintához viszonyítva a VFR az 50-59 éves korcsoport (15\%) és az alapfokú végzettséggel rendelkezők körében jellemzó (28\%) magasabb arányban. A hivatásturisztikai vagy munkavégzés céljából tett utazások szerepe szintén kiemelkedő (a teljes minta 14\%-a).

A kutatásba bevont személyek több, mint fele (55\%) a Covid19-pandémia ideje alatt egyáltalán nem venne részt nemzetközi utazáson, függetlenül attól, hogy az módjában állna-e (szabadidô, utazásra fordítható jövedelem). Az utazásokon való részvételi hajlandóság az életkor előrehaladtával folyamatosan csökken (pl. 18-29 éves korcsoport: $63 \%, 60-75$ éves korcsoport: 50\%). A válaszadók körében látható markáns elutasító magatartás ellenére azonban az alanyok 34\%-a egyetért abban, hogy a repülésben rejló közegészségügyi kockázat nem erősödött a járványhelyzet során.

Válaszadóink körében növekvő tudatosság mutatkozik a higiéniai szabálykövetést illetően. A teljes minta $60 \%$-a - bevallása szerint - körültekintóbb lesz a higiéniai szabályok betartásával kapcsolatban jövőbeli (a pandémia utáni időszakban) repülóvel történő nemzetközi utazásai során A tudatosság nagyobb arányban jellemző az idôsebb (50-59 éves korcsoport: 52\%), és a magukat középosztályba soroló válaszadók körében.

\section{5. Összefoglalás}

A Covid19-világjárvány gazdasági-turisztikai hatásaival foglalkozó szakirodalom, valamint az iparági jelentések rámutattak, hogy a szektor járvány utáni fellendülése nagyban függ a társadalom közlekedési módokkal és turisztikai szolgáltatásokkal szembeni bizalmának erősítésétől, ezért szükségszerú a lakosság attitúdjének folyamatos monitorozása.
A tanulmányban bemutatott kutatási eredmények rámutattak, hogy a SARS-COV-2 vírus okozta világjárvány az utazási szokások időszakos átrendeződését eredményezte a lakosság körében. A fókuszcsoportos beszélgetések alapján láthattuk, hogy a mindennapi helyváltoztatások során a közösségi közlekedés szerepe visszaszorult, a személygépkocsival történő közlekedés és a kerékpárhasználat azonban erósödött. A turisztikai szokásváltozásokkal kapcsolatban a kutatásba bevont alanyok túlnyomó többsége kiemelte, hogy a belföldi turizmus erősödése inkább rövid távon, elsôsorban a szenior korcsoport körében, a rekreációs és/vagy VFR turizmus iránti motiváció miatt lesz tapasztalható. Az alanyok egyetértettek abban, hogy a pandémia lefolyását követően a nemzetközi turizmus hirtelen fellendülése valószínúsíthető.

A fókuszcsoportokban feltárt személyközlekedési változásokat a kérdőíves adatfelvétel adatai is megerôsítették. A személygépjármúvel történő közlekedés - a válaszadók túlnyomó többsége szerint - a legbiztonságosabb közlekedési mód a pandémia idószakában. Ezzel szemben a személygépkocsi-használatra épülő megosztáson alapuló mobilitási formák (pl. telekocsi-szolgáltatás) a válaszadók értékelése alapján a legkockázatosabb utazási formák, így ez alapján elóre jelezhetô a megosztáson alapuló közlekedési piac teljesítményének időszakos gyengülése a Covid19 hatására.

A kérdőíves kutatás adatai alapján beigazolódott, hogy a lakosság körében a pandémia időszakában jelentôsen megváltozott a nemzetközi turizmus megítélése. A válaszadók több, mint fele nem utazott repülővel a Covid19-világjárvány időszakában, a turisztikai célú utazások szerepe a vizsgált időszakban marginális volt.

A kutatás fontos eredménye, hogy a válaszadók a pandémia alatt nem csupán a korlátozó intézkedések, utazási szabályozások miatt nem utaztak. A kutatásba bevont személyek több, mint fele a járvány megfékezéséig egyáltalán nem venne részt turisztikai célú nemzetközi utazásokon, függetlenül attól, hogy az módjában állna-e. A fókuszcsoport esetében tapasztalt lakossági attitúddel öszszehasonlítva a reprezentatív kérdőíves felmérés sokkal óvatosabb, kockázatkerülőbb magatartást mutat. A válaszadók jelentôs része a jövóbeli (a pandémia utáni időszakban) turisztikai céllal teendô utazásai során is körültekintőbb lesz a higiéniai szabályok betartását illetően.

A válaszok alapján megállapítható, hogy a szigorúbb higiéniás körülmények biztosítása iránti erősödó igény tudatában érdemes újragondolni a közlekedési és turisztikai szolgáltatások hagyományos konstrukcióját (pl. repülók férőhelye, fedélzeti szolgáltatások, reptéri check-in és egészségügyi 
ellenőrzések, szálláshelyek és egyéb szolgáltatók, attrakciók járványügyi védekezése).

Összességében elmondható, hogy a jelenlegi, egyéni mobilitási lehetôségeket kiterjesztô intézkedések 2021 második felében is erősíthetik a turisztikai szolgáltatások iránti keresletet (2020 nyarához hasonlóan), ugyanakkor a járvány leküzdéséig továbbra is fennáll a lakosság kockázatkerülő attitû́dje, így a turizmus sikeres újraindításának érdekében kiemelten fontos a fogyasztók megváltozott igényeihez való alkalmazkodás.

A fenti eredményekből kiindulva a további kutatások célja a fogyasztói bizalmat erósítő alternatívák feltárása a közlekedésben és a turizmusban, valamint az egyes egészségvédelmi intézkedések iránti igény tartósságának (pl. fizikai távolságtartás a repülőkön, turisztikai szolgáltatók biztonsági intézkedései) felmérése a lakosság körében.

\section{Felhasznált irodalom}

BABBIE, E. R. (2015): The Practice of Social Research. Nelson Education: Toronto, ON, Canada.

BAKAR, N. A. - ROSBI, S. (2020): Effect of Coronavirus disease (COVID-19) to tourism industry. International Journal of Advanced Engineering Research and Science (IJAERS). 7(4). pp. 189-193. https://dx.doi.org/10.22161/ijaers.74.23

BAUM, T. - HAI, N. T. T. (2020): Hospitality, tourism, human rights and the impact of COVID-19. International Journal of Contemporary Hospitality Management. 32(7). pp. 2397-2407. https://doi.org/10.1108/IJCHM-03-2020-0242

FELKAI P. (2021): Hogyan utazzunk a COVID járvány után? Turizmus Bulletin. 21(1). pp. 44-48. DOI: 10.14267/TURBULL.2021v21n1.5

HIGGINS-DESBIOLLES, F. (2020): The "war over tourism": challenges to sustainable tourism in the tourism academy after COVID-19. Journal of Sustainable Tourism. 29(4). pp. 551-569. https://doi.org/10.1080/09669582.2020.1803334

JÁSZBERÉNYI M. - PÁLFALVI J. (szerk.) (2009): Nemzetközi közlekedés és turizmus. Aula Kiadó, Budapest.

JOO, H. - MASKERY, B. A. - BERRO, A. D. ROTZ, L. D. - LEE, Y. K. - BROWN, C. M. (2019): Economic impact of the 2015 MERS outbreak on the Republic of Korea's tourismrelated industries. Health security. 17(2). pp. 100-108. https://doi.org/10.1089/hs.2018.0115

MALHOTRA, N. K. - DASH, S. (2016): Marketing research: An applied orientation. Pearson.

MICHALKÓ G. - ILYÉS N. (2020): A nemkonvencionális turisztikai mobilitás magyaror- szági sajátosságai, különös tekintettel a turizmusból származó bevételek növelésének lehetőségére. Turizmus Bulletin. 20(5). pp. 6-18.

DOI: 10.14267/TURBULL.2020v20n4.1

MISKOLCZI, M. - JÁSZBERÉNYI, M. - TÓTH, D. (2021): Technology-Enhanced Airport Services Attractiveness from the Travelers' Perspective. Sustainability. 13(2). pp. 1-18. https://doi.org/10.3390/su13020705

MUNKÁCSY A. (2018): A közlekedés alapfogalmai, a közlekedés szerepe a turizmusban. In: Jászberényi M. - Munkácsy A. (szerk.): Közlekedés, mobilitás, turizmus. Akadémiai Kiadó, Budapest.

QIU, R. T. - PARK, J. - LI, S. - SONG, H. (2020): Social costs of tourism during the COVID-19 pandemic. Annals of Tourism Research. 84. https://doi.org/10.1016/j.annals.2020.102994

ŠKARE, M. - SORIANO, D. R. - PORADAROCHOŃ, M. (2021): Impact of COVID-19 on the travel and tourism industry. Technological Forecasting and Social Change. 163. https://doi.org/10.1016/j.techfore.2020.120469

UNTWO (2020): UNWTO World Tourism Barometer, December 2020. 18(7). pp. 1-36.

\section{Internetes források}

EC (European Commission) (2021): Travel during the coronavirus pandemic. https://ec.europa. eu/info/live-work-travel-eu/coronavirusresponse/travel-during-coronaviruspandemic_en, Letöltve: 2021. május 10.

ETC (European Travel Commission) (2021): Europeans Increasingly Eager to Travel during Spring 2021 as COVID-19 Vaccine Rollout Begins. https://etc-corporate.org/news/europeansincreasingly-eager-to-travel-during-spring2021-as-covid-19-vaccine-rollout-begins/, Letöltve: 2021. május 10.

GLOBALDATA (2021): Direct booking providers will have 'window of opportunity' in post-pandemic travel. https://www.globaldata.com/directbooking-providers-will-window-opportunitypost-pandemic-travel/, Letöltve: 2021. május 10.

IFC (International Finance Corporation) (2020): The Impact of COVID-19 on Airports: An Analysis. https://www.ifc.org/wps/ wcm/connect/26d83b55-4f7d-47b1-bcf301eb996df35a/IFC-Covid19-Airport FINAL_ web3.pdf?MOD=AJPERES\&CVID=n81gpkG, Letöltés: 2021. május 10.

KSH (2021a): Távmunkát végzók a munkaerôpiacon. https://www.ksh.hu/docs/hun/modsz/ modsz917.html, Letöltve: 2021. május 10. 
KSH (2021b): A bruttó hazai termék (GDP) értéke, volumenindexe és explicit árindexe. https://www. ksh.hu/stadat_eves_3_1, Letöltve: 2021. május 10.

KSH (2021c): Budapest Liszt Ferenc Repülötér forgalma országonként. https://www.ksh.hu/ docs/hun/xstadat/xstadat_evkozi/e_odmj001. html, Letöltve: 2021. május 10.

UNWTO (2021): International Tourismand COVID-19. https://www.unwto.org/international-tourismand-covid-19, Letöltve: 2021. augusztus 2.

WHO (2021): COVID-19 reports. https://www. who.int/emergencies/diseases/novel-corona-
virus-2019/interactive-timeline?gclid=Cj0KCQjws-OEBhCkARIsAPhOkIZDBnLVYOziq2zg10saz4OoJ8j7AXIbrUjadEe8fWY7wd0CvIbCI2YaAtZvEALw_wcB\#event-115, Letöltve: 2021. május 10.

WORLD BANK (2007): China Severe Acute Respiratory Syndrome (SARS) and Infectious Diseases Response Program. https://documents. worldbank.org/en/publication/documentsreports/documentdetail/627391468214499938/ china-severe-acute-respiratory-syndrome-sarsand-infectious-diseases-response-program, Letöltve: 2021. május 10. 